\title{
The Relationship of Inflammation Parameters with Obstruction in Coronary Artery Ectasia
}

\section{Koroner Arter Ektazisinde İnflamasyon Parametrelerinin Obstrüksiyonla İlișkisi}

\author{
$\underline{\text { Idris Buğra CERRiK }}^{1 \cdot(\mathbb{D})}$, Ferhat DiNDAŞ ${ }^{1} \mathbb{D}$, Sefa Erdi ÖMÜR ${ }^{1}(\mathbb{D})$ Mustafa YENERÇAĞ $^{2}(\mathbb{D})$ \\ ${ }^{1}$ Department of Cardiology, Faculty of Medicine, Cumhuriyet University, Sivas, TURKEY \\ 2 Department of Cardiology, Faculty of Medicine, Ordu University, Ordu, TURKEY
}

\begin{abstract}
Background: Coronary artery ectasia (CAE) is a coronary artery disease that can progress in a wide clinical spectrum, from asymptomatic cases to stable angina pectoris or acute coronary syndrome. CAE can present with an acute coronary syndrome without an obstructive lesion. Although many studies comparing isolated CAE with normal coronary arteries and coronary artery disease, CAE patients with obstructive type lesions (obstructive CAE) have never been evaluated. In this study, we aimed to compare obstructive CAE patients and isolated CAE patients in terms of various inflammatory parameters.

Materials and Methods: A total of 190 patients were enrolled, including 95 obstructive CAE patients and 95 age and sex-matched isolated CAE patients. All participants were evaluated in the study consisted of patients admitted to the emergency department and diagnosed with NSTE-ACS. Systemic inflammatory parameters such as Platelet/lymphocyte ratio (PLR), Neutrophil/lymphocyte ratio (NLR), Monocyte/HDL ratio, CRP and sedimentation of the patients, were compared between two groups.

Results: CRP value was found significantly higher in obstructive CAE, compared to isolated CAE [5.5 (3.09.0) $\mathrm{mg} / \mathrm{L}, 4.0(3.0-6.0) \mathrm{mg} / \mathrm{L}(\mathrm{P}=0.003)$ respectively]. $P L R$ value was found significantly higher in obstructive CAE compared to isolated CAE [143 $\pm 76,120 \pm 45(p=0.015)$ respectively]. In multivariable logistic regression analysis, only CRP was an independent predictor of obstruction in CAE [OR:1.075 (1.011-1.142), $\mathrm{p}=0.021]$.

Conclusions: To the best of our knowledge, this study is the first to evaluate the effects of obstructive lesions on inflammatory parameters in patients with CAE presenting with acute coronary syndrome. We have shown that systemic inflammation is increased in the presence of obstructive coronary artery disease in CAE patients.
\end{abstract}

Key Words: Coronary artery ectasia, Myocardial infarction, Inflammation, CRP

ÖZ.

Amaç: Koroner arter ektazisi (CAE), asemptomatik vakalardan, stabil anjina pectoris ve hatta akut koroner sendroma kadar geniş bir klinik spektrumda karşımıza çıkabilen bir koroner arter hastalığıdır. CAE, tıkayıCı bir lezyon olmaksızın akut koroner sendromla ortaya çıkabilir. İzole CAE'yi normal koroner arterler ve koroner arter hastalığı ile kıyaslayan birçok çalışma olmasına ragmen obstrüktif tipte lezyonu olan CAE hastaları (obstruktif $C A E$ ) daha önce hiç değerlendirmeye alınmamıştır. Biz bu çalışmada obstrüktif CAE hastaları ile izole CAE hastalarını çeşitli inflamatuvar parametreler açısından kıyaslamayı amaçladık.

Materyal ve Metod: Çalışmaya 95 obstrüktif CAE hastası ve 95 yaş ve cinsiyet uyumlu izole CAE hastası dahil olmak üzere toplam 190 hasta dahil edildi. Çalışmada tüm katılımcılar acil servise başvuran ve NSTEAKS tanısı alan hastalardan oluşturuldu. İki grup arasında Platelet/lenfosit oranı (PLR), Nötrofil/lenfosit oranı (NLR), Monosit / HDL oranı, CRP ve sedimantasyon gibi sistemik inflamatuar parametreler karşılaştırıldı.

Bulgular: CRP değeri, obstrüktif CAE'de izole CAE'ye göre anlamlı olarak yüksek bulundu [sırasıyla, 5.5 (3.09.0) $\mathrm{mg} / \mathrm{L}, 4.0(3.0-6.0) \mathrm{mg} / \mathrm{L}(\mathrm{p}=0.003)]$. İzole CAE'ye göre obstrüktif CAE'de PLR değeri anlamlı olarak daha yüksek bulundu [sırasıyla, $120 \pm 45,143 \pm 76(p=0.015)$ ]. Çok değişkenli lojistik regresyon analizinde, yalnızca CRP, CAE'deki tıkanıklığın bağımsız bir öngörücüsü olarak saptandı [OR:1.075 (1.011-1.142), $\mathrm{p}=0.021]$

Sonuç: Bildiğimiz kadarıyla bu çalışma, akut koroner sendromla başvuran CAE hastalarında obstruktif tipte lezyonların inflamatuvar parametrelere etkisini değerlendiren ilk çalışmadır. Bu çalışmada CAE hastalarında obstrüktif koroner arter hastalığı varlığında sistemik inflamasyonun arttığını gösterdik.

Anahtar kelimeler: Koroner arter ektazisi, Miyokard infarktüsü, İnflamasyon, CRP
Corresponding Author / Sorumlu Yazar

Dr. İdris Buğra ÇERIK

Department of Cardiology, Faculty of

Medicine, Cumhuriyet University, Sivas, TURKEY

E-mail: cerikbugra@gmail.com

Received / Geliş Tarihi: 30.11.2020

Accepted / Kabul Tarihi: 12.03.2021

DOI: $10.35440 /$ hutfd. 833532

This research article was accepted as an oral presentation at the 36th Turkish Cardiology Congress with International Participation. 3-6 December 2020, Digital congress 


\section{Introduction}

Coronary artery ectasia (CAE) is a coronary artery disease of which prevalence is observed between $0.3 \%$ and $5 \%$ in angiographic studies, which is defined as $\geq 1.5$-fold dilation of the epicardial coronary artery compared to the normal segment $(1,2)$. Although congenital origin, bacterial infections and connective tissue diseases are faulted in $\mathrm{CAE}$ etiology, atherosclerotic coronary artery disease accompanies the majority of patients (3). Lipid deposition with foamy cells, fibrous cap, hyalinization and degeneration of the media layer, are shown histopathologically in the CAE $(4,5)$.

The mechanism leading to dilatation of coronaries in $\mathrm{CAE}$ is not completely clear, but histopathological findings are similar to atherosclerosis. These findings may result from increased inflammation and it has therefore been shown in many studies, that inflammatory markers such as Neutrophil/lymphocyte ratio (NLR), Monocyte/HDL ratio, Creactive protein (CRP) increase in isolated coronary artery ectasia, compared to patients with normal coronary arteries and those with obstructive coronary artery disease (613). As the severity of ectasia increased, inflammatory parameters has also reportedly increased (7). Platelet lymphocyte ratio (PLR) is a prognostic and diagnostic marker associated with in-hospital mortality and major cardiac adverse events, in acute coronary syndrome (14). Previous studies have revealed that PLR shows a positive correlation with the severity of ectasia in isolated CAE (8). Obstructive lesions are not uncommon in patients with coronary artery ectasia (2). Moreover, it is unclear why these develop in some patients with coronary artery ectasia. They may be a result of increased inflammatory status in patients with CAE and it may be possible to evaluate these changes with inflammatory parameters. In this study on patients with non-ST segment elevation acute coronary syndrome (NSTE-ACS), we aimed to evaluate the effect of obstructive lesions on inflammatory parameters in patients with CAE.

\section{Materials and Methods Patient Selection}

In this study, patients diagnosed with NSTE-ACS and coronary artery ectasia in a local university hospital between January 2015 and December 2019 were screened retrospectively. Admission diagnosis, demographic and clinical features of the patients were obtained from electronic health records. Patients with a diagnosis of heart failure, with a previous percutaneous coronary intervention ( $\mathrm{PCl}$ ) and/or coronary artery bypass graft (CABG), those with inflammatory disease, with chronic obstructive pulmonary disease, with chronic kidney disease, with chronic liver disease, with malignancy, as well as those with an active infection during the admission, were all excluded from the study. A total of 190 patients were enrolled, including 95 obstructive CAE patients and 95 age and sex-matched isolated CAE patients. All participants who were evaluated in the study consisted of patients admitted to the emergency department and diagnosed with NSTE-ACS. The diagnosis of NSTE-ACS was made in accordance with the contemporary ESC guidelines of the period (15).

The study received institutional permission from the university hospital where it was conducted, as well as the approval from the ethics committee of the university (CUTF: 2019-10/08). Informed consent forms were obtained from all patients and with the approval of the ethics committee, verbal consent was obtained by telephone contact from the patients who could not provide a written statement. In the case of repeated blood pressure measurements of $>140 / 90 \mathrm{mmHg}$ or antihypertensive drug usage, arterial hypertension was considered. Patients with at least two fasting blood glucose levels measured as $\geq 126 \mathrm{mg} / \mathrm{dl}$, with $\mathrm{HbA} 1 \mathrm{C}$ level $>6.5 \%$ or taking antidiabetic medication, were considered to have diabetes mellitus disease. The presence of hyperlipidemia was considered in patients with a total serum cholesterol level of $>200 \mathrm{mg} / \mathrm{dl}$ or who were using lipid-lowering medication.

Transthoracic echocardiography (TTE) was performed on all patients with Vivid E7 (GE Vingmed Ultrasound) echocardiography device and MS5 (1.5-4.5 MHz) ultrasound probe, before coronary angiography. Left ventricular ejection fraction (LVEF) was measured using the Simpson method.

\section{Blood Samples Measurement}

Basic blood test parameters at the time of admission with acute coronary syndrome were recorded for all patients. All measurements were performed within 30 minutes after blood collection. An automatic blood cell counter (Beckman, California) was used to complete blood count measurement. Sedimentation, fasting blood glucose, lipid panel, serum electrolytes, thyroid function tests, blood urea nitrogen (BUN), troponin and creatinine levels of all patients, were recorded. C-reactive protein (CRP) measurement was done using an automatized analyzer (Beckman Coulter analyzer, California) using nephelometric measurement before the coronary angiography.

\section{Coronary angiography}

All angiographic imaging was performed with the Philips Allura Xper Percutaneous Coronary Intervention system. Femoral intervention with standard Judkins technique and $6 \mathrm{Fr}$ catheter was used for all patients.

CAE was defined as $a \geq 1.5$ fold dilatation of the epicardial coronary artery relative to the normal segment (16). Poststenotic dilatations were not considered as coronary ectasia. Isolated CAE has been described as a condition without significant coronary stenosis. Obstructive coronary artery disease was considered in the presence of $>70 \%$ stenosis and ischemia evidence (FFR $<0.8$ or ischemia demonstrated by myocardial perfusion scintigraphy), $>90 \%$ stenosis in coronary arteries.

In the CAE classification made by Markis, diffuse dilation of 2 or 3 coronary arteries was classified as Type1 CAE, 
whereas diffuse dilation of one coronary artery with localized dilation in another vessel was classified as Type2 CAE, single-vessel diffuse dilatation as Type3 CAE and localized or segmental dilatation as Type4 CAE (16). In our study, we classified Markis Type 1 and Type 2 ectasia as severe ectasia, Type 3 and Type 4 ectasia as mild ectasia, in order to compare the severity of CAE and obstruction presence under a total of 4 groups of patients.

\section{Statistical Analysis}

The analysis of the data was performed with the TURCOSA (Turcosa Analytics Ltd Co, Turkey, www.turcosa.com.tr) statistical software. The significance level was determined as $p<0.05$. The suitability of the data for normal distribution was evaluated by a histogram, $q-q$ graphs and the Shapiro-Wilk test. The categorical variables were expressed as the number with a percentage. Normally distributed continuous data was expressed as mean \pm standard deviation, while continuous variables that are not normally distributed were specified as median (minimummaximum). Variance homogeneity was tested using the Levene test. In comparisons between two groups, independent two samples t-test and Mann Whitney $U$ test was used for continuous variables. Kruskal-Wallis tests were used in the comparisons of more than two groups. The Dunn-Bonferroni test was performed for multiple comparisons. The Chi-square analysis was used to compare categorical variables. Multivariate logistic regression analyses were carried out to determine the risk factors affecting the Obstructive Lesion status. Receiver operating characteristic (ROC) graphics were drawn and cut-off values were calculated to evaluate the predictability of lesion status with CRP variables in patients with ectasia. Sensitivity, specificity and area under the curve were calculated to evaluate diagnostic test performance.

\section{Results}

A total of 190 patients, 95 of whom were isolated CAE and 95 were CAE with obstructive coronary artery disease, were included in the study. Baseline demographic characteristics, clinical and angiographic data, basic laboratory tests, echocardiographic parameters of the patients are given in Table 1 and Table 2, respectively. There was no significant difference between the baseline demographic characteristics of the patients. In the isolated coronary ectasia group, ectasia in the Left anterior descending coronary artery (LAD) was higher compared to the obstructive CAE group [48(50.5\%), $32(33.7 \%)$, respectively $(p<0.05)]$. There was a significant difference in ectasia, which was determined as mild and severe between the groups $(p=0.027)$, and this difference was due to a higher prevalence of severe ectasia in the isolated CAE group than the obstructive CAE group [47(49.5\%), 32(33.7\%), respectively]. Although there was no significant difference in most of the basic hemogram and biochemical parameters, there was a significant difference between the groups in PLR and CRP. CRP value was found significantly higher in obstructive CAE compared to isolated CAE [5.5 (3.0-9.0) $\mathrm{mg} / \mathrm{L}, 4.0$ (3.0-6.0) $\mathrm{mg} / \mathrm{L}(\mathrm{P}=0.003)$, respectively]. PLR value was found to be significantly higher in obstructive CAE compared to isolated CAE $[143 \pm 76,120 \pm 45(p=0.015)$, respectively]. In multivariate logistic regression analysis, CRP was determined as an independent variable [OR:1.075 (1.011-1.142), p=0.021] (Table 3).

Table 1. Comparison of demographic and angiographic features of obstructive CAE and isolated CAE patients

\begin{tabular}{|c|c|c|c|}
\hline \multirow[b]{2}{*}{ Variables } & \multicolumn{2}{|c|}{ Group } & \multirow[b]{2}{*}{$p$-value } \\
\hline & $\begin{array}{l}\text { Isolated CAE } \\
(n=95)\end{array}$ & $\begin{array}{l}\text { Obstructive CAE } \\
(n=95)\end{array}$ & \\
\hline Age, years & $60.56 \pm 10.11$ & $60.77 \pm 10.27$ & 0.887 \\
\hline $\begin{array}{l}\text { Gender (Female) } \\
\mathrm{n},(\%)\end{array}$ & $22(23.2)$ & $13(13.7)$ & 0.134 \\
\hline Smoking n,(\%) & $36(37.9)$ & $49(51.6)$ & 0.058 \\
\hline DM n,(\%) & $16(16.8)$ & $19(20.0)$ & 0.708 \\
\hline HL n,(\%) & $25(26.3)$ & $34(35.8)$ & 0.158 \\
\hline HT n,(\%) & $51(53.7)$ & $48(50.5)$ & 0.663 \\
\hline ARB/ACEi n,(\%) & $41(43.2)$ & $36(37.9)$ & 0.460 \\
\hline CCB n,(\%) & $21(22.1)$ & $13(13.7)$ & 0.185 \\
\hline Beta Blocker n,(\%) & $37(38.9)$ & $48(50.5)$ & 0.109 \\
\hline \multicolumn{4}{|l|}{ NSTE-ACS } \\
\hline USAP n,(\%) & $34(35.8)$ & $37(38.9)$ & 0.653 \\
\hline $\mathrm{MI} n,(\%)$ & $61(64.2)$ & $58(61.1)$ & \\
\hline \multicolumn{4}{|l|}{ Ectasia } \\
\hline LAD n,(\%) & $48(50.5)$ & $32(33.7)$ & 0.019 \\
\hline CX n,(\%) & $43(45.3)$ & $43(45.3)$ & 0.999 \\
\hline RCA $n,(\%)$ & $57(60.0)$ & $53(55.8)$ & 0.557 \\
\hline \multicolumn{4}{|l|}{ Ectasia Severity } \\
\hline Mild n,(\%) & $48(50.5)$ & $63(66.3)$ & 0.027 \\
\hline Severe $n,(\%)$ & $47(49.5)$ & $32(33.7)$ & \\
\hline \multicolumn{4}{|l|}{ Obstructive Lesion } \\
\hline LMCA n,(\%) & & $6(6.3)$ & \\
\hline LAD $n,(\%)$ & & $71(74.7)$ & \\
\hline$C \times n,(\%)$ & & $41(43.2)$ & \\
\hline RCA n,(\%) & & $51(53.7)$ & \\
\hline 3 VD n,(\%) & & $21(22.1)$ & \\
\hline \multicolumn{4}{|l|}{ Decision } \\
\hline $\begin{array}{l}\text { Medical follow-up } \\
n,(\%)\end{array}$ & $95(100)$ & $1(1.1)$ & \\
\hline $\mathrm{PCl} n,(\%)$ & & $54(56.8)$ & \\
\hline CABG n,(\%) & & $40(42.1)$ & \\
\hline
\end{tabular}

DM: Diabetes mellitus, HT: Hypertension, HL: Hyperlipidemia, ARB: Angiotensin receptor blocker, ACEi: Angiotensin converting enzyme inhibitor, CABG: Coronary artery bypass graft, CCB: Calcium channel blocker, NSTEACS: Acute coronary syndromes without ST-elevation, USAP: Unstable angina pectoris, LMCA: Left main coronary artery, LAD: Left anterior descending artery, MI: Myocardial infarction, CX: Left circumflex artery, RCA: Right coronary artery, PCI: Percutaneous coronary intervention, 3 VD: Three vessel coronary artery disease.

Patients with Markis type 1 and type 2 ectasia were categorized as severe ectasia, and patients with Markis type 3 and type 4 ectasia were categorized as mild ectasia; the difference in inflammation markers is given in Table 4. No statistically significant relationship was found between the groups in terms of the Neutrophil/lymphocyte ratio (NLR) variable $(p>0.05)$. The CRP level was found to be statistically different between the groups $(p=0.023)$. This difference was due to the CRP level of patients in the mild and severe ectasia group in isolated CAE [4.3 (3.0-5.3), 4.0 (3.0-6.0) $\mathrm{mg} / \mathrm{L}$, respectively] being lower than the patients in the severe ectasia group with obstructive CAE [6.0(3.19.2) $\mathrm{mg} / \mathrm{L}$. CRP values stratified by the presence of obstruction and the severity of ectasia in CAE are given in 
Figure 1 . The PLR variable was found to be statistically different between the groups $(p=0.003)$. This difference is the result of the PLR value of the patients in the mild ectasia group in the isolated CAE $(107.14 \pm 36.09)$ found to be lower than the patients in the severe and mild group with obstructive CAE $(163.77 \pm 107.84,132.88 \pm 51.28$, respectively). The Monocyte/HDL ratio variable was found to be statistically different between the groups $(p=0.018)$. This difference is the result of the Monocyte/HDL ratio value of the patients in the mild ectasia with isolated $C A E$ [14.2(10.0-16.7)], and severe ectasia with obstructive CAE [14.3(10.3-18.9)], having been found to be lower than the patients in the mild ectasia with obstructive CAE [17.4(13.8-21.4)].

Table 2. Comparison of laboratory and echocardiographic parameters of obstructive CAE and isolated CAE patients

\begin{tabular}{|c|c|c|c|}
\hline \multirow[t]{2}{*}{ Variables } & \multicolumn{2}{|c|}{ Group } & \multirow[b]{2}{*}{$\begin{array}{c}P \\
\text { value }\end{array}$} \\
\hline & $\begin{array}{c}\text { Isolated CAE } \\
(n=95)\end{array}$ & $\begin{array}{c}\begin{array}{c}\text { Obstructive CAE } \\
(n=95)\end{array} \\
\end{array}$ & \\
\hline $\mathrm{RBC},\left(10^{6} / \mathrm{uL}\right)$ & $4.94 \pm 0.74$ & $4.92 \pm 0.76$ & 0.828 \\
\hline Neutrophil (103/uL) & $5.4(4.0-8.0)$ & $5.7(4.0-8.0)$ & 0.722 \\
\hline Lymphocyte (103/uL) & $2.0(2.0-3.0)$ & $1.93(1.0-3.0)$ & 0.999 \\
\hline Monocyte (103/uL) & $0.5(0.0-1.0)$ & $0.6(0.0-1.0)$ & 0.151 \\
\hline $\mathrm{Hb}(\mathrm{g} / \mathrm{dl})$ & $14.7(13.0-16.0)$ & $15.0(13.0-16.0)$ & 0.605 \\
\hline Platelet $\left(10^{3} / \mathrm{uL}\right)$ & $\begin{array}{c}243.0(190.0- \\
290.0)\end{array}$ & $254.0(209.0-306.0)$ & 0.236 \\
\hline Glucose (mg/dl) & $\begin{array}{c}111.0(96.0- \\
143.0)\end{array}$ & $113.0(99.0-137.0)$ & 0.767 \\
\hline Triglyceride (mg/dl) & $\begin{array}{c}128.0(88.0- \\
172.0)\end{array}$ & $141.0(101.0-179.0)$ & 0.355 \\
\hline HDL, (mg/dl) & $36.0(30.0-45.0)$ & $35.0(29.0-40.0)$ & 0.229 \\
\hline LDL (mg/dl) & $\begin{array}{c}112.0(81.0- \\
144.0)\end{array}$ & $114.0(90.0-136.0)$ & 0.589 \\
\hline Monocyte /HDL ratio & $14.3(10.0-18.0)$ & $16.7(12.0-21.0)$ & 0.051 \\
\hline PLR & $120.11 \pm 45.35$ & $143.63 \pm 76.72$ & 0.015 \\
\hline NLR & $2.7(2.0-5.0)$ & $3.0(2.0-4.0)$ & 0.874 \\
\hline Creatinine $(\mathrm{mg} / \mathrm{dl})$ & $0.9(1.0-1.0)$ & $1.0(1.0-1.0)$ & 0.825 \\
\hline $\operatorname{ALT}(\mathrm{U} / \mathrm{L})$ & $23.0(15.0-31.0)$ & $23.0(15.0-32.0)$ & 0.816 \\
\hline AST (U/L) & $25.0(19.0-37.0)$ & $23.0(18.0-40.0)$ & 0.560 \\
\hline Sedimentation $(\mathrm{mm} / \mathrm{h})$ & $7.5(5.0-11.0)$ & $7.0(5.0-12.0)$ & 0.991 \\
\hline $\operatorname{CRP}(\mathrm{mg} / \mathrm{L})$ & $4.0(3.0-6.0)$ & $5.5(3.0-9.0)$ & 0.003 \\
\hline TSH (mIU/L) & $1.1(1.0-2.0)$ & $1.2(1.0-2.0)$ & 0.518 \\
\hline Troponin (ng/mL) & $0.29(0.0-1.56)$ & $0.23(0.0-2.46)$ & 0.757 \\
\hline$E F, \%$ & $55.0(50.0-60.0)$ & $55.0(50.0-57.0)$ & 0.443 \\
\hline $\begin{array}{l}\text { Ascending aorta diame- } \\
\text { ter }(\mathrm{cm})\end{array}$ & $2.7(3.0-3.0)$ & $2.7(3.0-3.0)$ & 0.583 \\
\hline
\end{tabular}

RBC: Red blood cell, Hb: Hemoglobin, HDL: High density lipoprotein, LDL: Low density lipoprotein , PLR: Platelet to Lymphocyte ratio, NLR: Neutrophil to Lymphocyte ratio, ALT: Alanine aminotransferase, AST: Aspartate aminotransferase, CRP: C reactive protein, TSH: Thyroid stimulating hormone, EF: Ejection fraction.

Table 3. Multivariate logistic regression analysis showing independent predictors of obstruction in coronary artery ectasia

\begin{tabular}{lccccc}
\hline & & & & \multicolumn{2}{c}{$\% 95$ Confidence interval } \\
\cline { 5 - 6 } \multicolumn{1}{c}{ Variables } & OR & S.E & $\mathbf{p}$ & Lower & Upper \\
\hline Troponin I & 1,012 & 0,026 & 0,647 & 0,962 & 1,064 \\
CRP & 1,075 & 0,031 & $\mathbf{0 , 0 2 1}$ & 1,011 & 1,142 \\
Age & 1,004 & 0,016 & 0,783 & 0,974 & 1,035 \\
LDL & 1,004 & 0,004 & 0,346 & 0,996 & 1,011 \\
PLR & 1,003 & 0,003 & 0,243 & 0,998 & 1,008 \\
Monocyte /HDL ra- & 1,024 & 0,017 & 0,147 & 0,992 & 1,058 \\
tio &, 888 & 0,068 & 0,079 & 0,777 & 1,014 \\
NLR & & &
\end{tabular}

CRP: C reactive protein, HDL: High density lipoprotein, $L D L$ : Low density lipoprotein, NLR: Neutrophil to Lymphocyte ratio, OR: Odds ratio, PLR: Platelet to Lymphocyte ratio, S.E.: Standard error

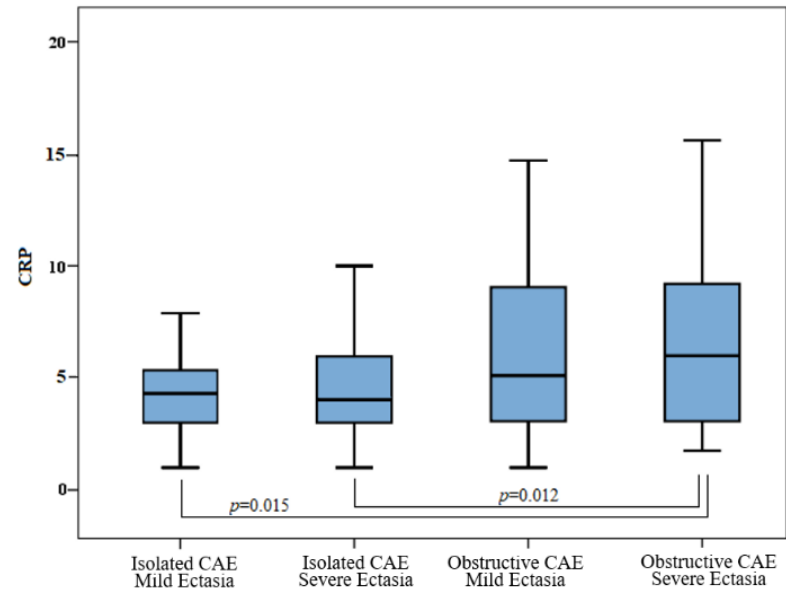

Fig 1. Comparison of CRP between groups

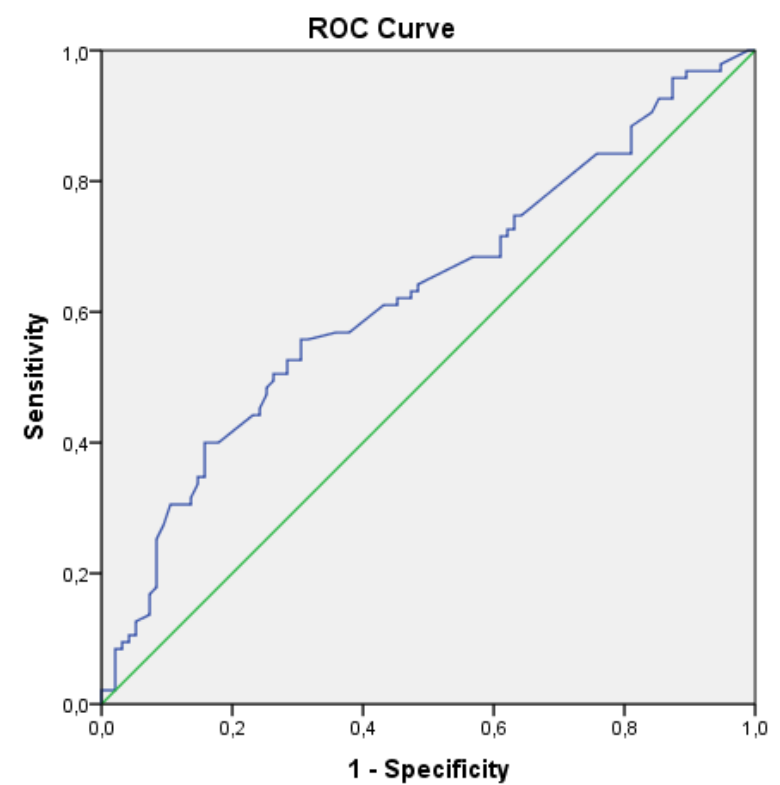

Fig 2. ROC analysis of CRP in distinguishing isolated CAE and obstructive CAE

Table 4. Comparison of obstructive CAE, isolated CAE and ectasia severity.

\begin{tabular}{|c|c|c|c|c|c|}
\hline \multirow[b]{2}{*}{ Variables } & \multicolumn{4}{|c|}{ Group } & \multirow[b]{2}{*}{$\begin{array}{c}P \\
\text { value }\end{array}$} \\
\hline & $\begin{array}{l}\text { Isolated } \\
\text { CAE Mild } \\
\text { Ectasia } \\
(n=47)\end{array}$ & $\begin{array}{c}\text { Isolated } \\
\text { CAE } \\
\text { Severe } \\
\text { Ectasia } \\
(n=48)\end{array}$ & $\begin{array}{c}\text { Obstruc- } \\
\text { tive CAE } \\
\text { Mild } \\
\text { Ectasia } \\
(n=63)\end{array}$ & $\begin{array}{c}\text { Obstruc- } \\
\text { tive CAE } \\
\text { Severe } \\
\text { Ectasia } \\
(n=32)\end{array}$ & \\
\hline $\begin{array}{l}\text { Sedimenta- } \\
\text { tion }\end{array}$ & $\begin{array}{c}7.0 \\
(4.0-11.0)\end{array}$ & $\begin{array}{c}8.0 \\
(5.0-12.5)\end{array}$ & $\begin{array}{c}7.0 \\
(5.0-12.0)\end{array}$ & $\begin{array}{c}7.5 \\
(5.0-10.5)\end{array}$ & 0.866 \\
\hline CRP & $\begin{array}{c}4.3 \\
(3.0-5.3)^{\mathrm{a}}\end{array}$ & $\begin{array}{c}4.0 \\
(3.0-6.0)^{\mathrm{a}}\end{array}$ & $\begin{array}{c}5.1 \\
(3.0-9.1)^{\mathrm{ab}}\end{array}$ & $\begin{array}{c}6.0 \\
(3.1-9.2)^{b}\end{array}$ & 0.023 \\
\hline PLR & $\begin{array}{c}107.14 \\
\pm 36.09^{\mathrm{a}}\end{array}$ & $\begin{array}{c}131.39 \\
\pm 49.76^{\mathrm{ab}}\end{array}$ & $\begin{array}{c}132.88 \\
\pm 51.28^{\mathrm{b}}\end{array}$ & $\begin{array}{c}163.77 \\
\pm 107.84^{b}\end{array}$ & 0.003 \\
\hline NLR & $\begin{array}{c}2.4 \\
(1.7-5.0)\end{array}$ & $\begin{array}{c}2.9 \\
(2.0-4.5)\end{array}$ & $\begin{array}{c}3.0 \\
(2.3-4.0)\end{array}$ & $\begin{array}{c}2.9 \\
(1.5-4.0)\end{array}$ & 0.649 \\
\hline MONOSITHDL & $\begin{array}{c}14.2 \\
(10.0-16.7)^{\mathrm{a}}\end{array}$ & $\begin{array}{c}14.7 \\
(10.6- \\
21.5)^{\mathrm{ab}}\end{array}$ & $\begin{array}{c}17.4 \\
(13.8- \\
21.4)^{b}\end{array}$ & $\begin{array}{c}14.3 \\
(10.3-18.9)^{\mathrm{a}}\end{array}$ & 0.018 \\
\hline
\end{tabular}

CRP: C reactive protein, PLR: Platelet to Lymphocyte ratio, NLR: Neutrophil to Lymphocyte ratio

${ }^{a, b}$ Similar letters in the same line indicate similarity between groups, different letters represent difference between groups. 


\section{Discussion}

To the best of our knowledge, this is the first study comparing isolated CAE with obstructive CAE in terms of inflammatory parameters. Our results showed that obstructive lesions are associated with higher CRP levels in patients with $C A E$, and CRP is an independent predictor for obstructive CAE.

CAE etiology has not been fully clarified. Similar to atherosclerotic disease of the ectatic segment of the coronary artery, cholesterol and fat debris covered with a fibrous cap is observed, as well as the destruction and reduction occurring in the internal, external elastic lamina in medial elastic fibers $(16,17)$. No mechanism has been understood to explain all CAE patients and there is no treatment modality to prevent its progression (18). It is thought to be related to coronary artery disease in more than half of the patients (3). Subclinical LV dysfunction has been demonstrated by strain echocardiography, although LV functions of CAE patients were not altered by standard echocardiographic methods (19). As in coronary artery disease, it is more common in the male gender, and hypertension, smoking as well as hyperlipidemia are all risk factors (20, 21). In a study evaluating 91 CAE patients and 90 normal coronary participants, a significant difference was observed in total cholesterol, triglyceride (TG), high-density lipoprotein (HDL) and low-density lipoprotein levels in patients with CAE, compared to normal coronary; atherogenic dyslipidemia index (TG / HDL) was also determined as an independent predictor for CAE (22). There was no difference between the patient groups evaluated in this study in terms of the lipid panel. This may be the result that, although one group had obstructive coronary artery disease, both groups consisted of patients with CAE. Unlike other atherosclerotic risk factors, it has been shown that diabetes mellitus (DM) is not a risk factor for CAE. Moreover, a no positive relationship has been found between CAE and DM (23). In our findings, the majority of patients were male and had high smoking rates, and hypertension (HT) and hyperlipidemia (HPL) were common, but relative DM was observed in a lower ratio. Among these findings, there was no difference between isolated CAE and obstructive CAE.

One subject that has been studied in CAE pathogenesis in recent years is the presence of chronic inflammation, however it remains a matter of debate whether this inflammation is the result of atherosclerotic coronary artery disease. Vascular endothelial growth factor (VEGF), which induces the production of Matrix metalloproteinases, TNF-alpha and interleukin-6, has been shown to increase in isolated CAE $(9,10)$. Increased levels of I-CAM, V-CAM and E-selectin, which are soluble adhesion molecules, strengthened the hypothesis that vascular inflammation increased (11). The presence of increased systemic inflammation in CAE has since begun to be investigated. CRP level has been shown to be higher in isolated CAE patients than in obstructive coronary artery disease (12). Neutrophil-lymphocyte ratio (NLR) has been shown to be correlated with CRP in isolated CAE as another marker showing inflammation (13). Monocyte-HDL ratio was shown to increase in isolated CAE and this relationship was found to correlate with the severity of ectasia. In various studies conducted on the topic, comparisons were made between isolated CAE, normal coronary and obstructive coronary artery disease. In patients with coronary artery ectasia, obstructive coronary artery lesions are not scarce (2). Excessive acceleration of the inflammatory process in $\mathrm{CAE}$ patients can lead to the development of obstruction or, in other words, the acceleration of the mechanism causing CAE can be detected with systemic inflammatory markers. The NLR of the patients included in our study was not different between the two groups. The monocyte-HDL ratio was higher in obstructive CAE patients, but it was not statistically significant, though the CRP level, which is one of the most reliable parameters of systemic inflammation, was found to be significantly higher in obstructive CAE patients as an independent predictor.

The relationship between the increase of the platelet count (24) and the reduction of the lymphocyte count (25) with major cardiac adverse events has been demonstrated. Subsequent studies have shown that PLR is a good predictor in demonstrating an all-cause death in NSTE-ACS patients (14). In a study conducted in patients with stable angina, it was shown by Kundi et al. that PLR was higher in isolated CAE compared to obstructive coronary artery disease and normal coronary arteries, and that this was correlated with the severity of CAE (8). In previous studies, the effectiveness of PLR has been demonstrated in acute coronary syndrome. In NSTE-ACS patients evaluated in our study, the PLR value of obstructive CAE patients was significantly higher than isolated CAE, however the difference in the multivariate logistic regression analysis lost its statistical significance.

The association of CAE with obstructive coronary artery lesions is not rare (2). Although many studies have shown the relationship of CAE with inflammation in patients with stable angina, studies in which ACS and CAE are evaluated together are limited. In a study evaluating 60 patients who had primary $\mathrm{PCl}$ due to $\mathrm{AMI}$, obstructive CAE was shown to have higher inflammation markers, such as CRP and NLR, than the control group (26). In the study, although the authors stated that the high levels of the inflammation marker and the presence of CAE did not affect mortality, it is difficult to make this conclusion with this small-scale study. In previous studies, isolated CAE has been shown to have mortality rates similar to multi-vessel coronary artery disease (27). This may be related to an increased inflammatory condition. The relationship between CRP and increased mortality and cardiac adverse events have been known for a long time, in NTE-ACS $(28,29)$. 
Our study showed that the presence of obstructive lesions in CAE disease is characterized by increased inflammation in NSTE-ACS. We believe that prospective studies comparing obstructive CAE with other coronary artery diseases, will contribute greatly to the literature.

\section{Study limitations}

The most important limitation of our study is its retrospective design. The vascular wall was not evaluated by intravascular ultrasound and therefore an error might have occurred in the assessment of the severity of ectasia. Less expensive and more practical markers of the inflammation were used, therefore its correlation could not be performed with other vascular inflammatory parameters that showed to have increased in CAE. As a result of the low prevalence of the disease, the population included in the study can be considered low, although it was comparable to similar studies.

\section{Conclusion}

In this study in which the CAE causing NSTE-ACS was evaluated, we found that inflammation markers differ according to the presence or absence of obstructive lesions. CRP value, one of the most important markers of inflammation, is significantly higher in obstructive CAE compared to isolated CAE. We suggest that increased systemic inflammation in CAE patients accelerates the way to obstructive CAE and major cardiac adverse events may be more readily detected in this patient group.

\section{Acknowledgements}

We thank Özgür Tokgöz and Jean Yves Blanchard for the English editing of this manuscript.

Ethical Approval: The study was approved by the ethical committee of clinical research of the Cumhuriyet University non-interventional clinical research ethics committee (Ethics Committee Decision Number: 2019-10/08; Date: 09/10/2019).

\section{Author Contributions:}

Concept: I.B.C., F.D.

Literature Review: I.B.C., S.E.Ö.

Design : I.B.Ç., M.Y.

Data acquisition: F.D., S.E.Ö.

Analysis and interpretation: I.B.C., F.D.

Writing manuscript: i.B.Ç.

Critical revision of manuscript: M.Y.

Conflict of Interest: Authors declared no conflict of interest. Financial Disclosure: Authors declared no financial support.

\section{References}

1. Falsetti HL, Carrol RJ. Coronary artery aneurysm. A review of the literature with a report of 11 new cases. Chest. 1976;69(5):630-6.

2. Pinar Bermúdez E, López Palop R, Lozano Martínez-Luengas I, Cortés Sánchez R, Carrillo Sáez P, Rodríguez Carreras R, et al. [Coronary ectasia: prevalence, and clinical and angiographic characteristics]. Rev Esp Cardiol. 2003;56(5):473-9.

3. Manginas A, Cokkinos DV. Coronary artery ectasias: imaging, functional assessment and clinical implications. Eur
Heart J. 2006;27(9):1026-31.

4. Virmani $R$, Robinowitz $M$, Atkinson JB, Forman $M B$, Silver $\mathrm{MD}, \mathrm{McAllister} \mathrm{HA}$. Acquired coronary arterial aneurysms: an autopsy study of 52 patients. Hum Pathol. 1986;17(6):575-83.

5. Rath S, Har-Zahav Y, Battler A, Agranat O, Rotstein Z, Rabinowitz $B$, et al. Fate of nonobstructive aneurysmatic coronary artery disease: angiographic and clinical follow-up report. Am Heart J. 1985;109(4):785-91.

6. Li JJ, Nie SP, Qian XW, Zeng HS, Zhang CY. Chronic inflammatory status in patients with coronary artery ectasia. $\mathrm{Cy}$ tokine. 2009;46(1):61-4.

7. Sarli B, Baktir AO, Saglam H, Arinc H, Kurtul S, Sivgin S, et al. Neutrophil-to-lymphocyte ratio is associated with severity of coronary artery ectasia. Angiology. 2014;65(2):14751.

8. Kundi $H$, Gök $M$, Çetin $M$, Kızıltunç E, Çiçekcioğlu $H$, Güven Çetin Z, et al. Relationship between platelet-to-lymphocyte ratio and the presence and severity of coronary artery ectasia. Anatol J Cardiol. 2016;16(11):857-62.

9. Savino M, Parisi Q, Biondi-Zoccai GG, Pristipino C, Cianflone $D$, Crea F. New insights into molecular mechanisms of diffuse coronary ectasiae: a possible role for VEGF. Int J Cardiol. 2006;106(3):307-12.

10. Aydin M, Tekin IO, Dogan SM, Yildirim N, Arasli M, Sayin $M R$, et al. The levels of tumor necrosis factor-alpha and interleukin- 6 in patients with isolated coronary artery ectasia. Mediators Inflamm. 2009;2009:106145.

11. Turhan $H$, Erbay AR, Yasar AS, Aksoy Y, Bicer A, Yetkin G, et al. Plasma soluble adhesion molecules; intercellular adhesion molecule-1, vascular cell adhesion molecule- 1 and $\mathrm{E}-$ selectin levels in patients with isolated coronary artery ectasia. Coron Artery Dis. 2005;16(1):45-50.

12. Turhan H, Erbay AR, Yasar AS, Balci M, Bicer A, Yetkin E. Comparison of $\mathrm{C}$-reactive protein levels in patients with coronary artery ectasia versus patients with obstructive coronary artery disease. Am J Cardiol. 2004;94(10):1303-6.

13. Erayman A, Sen N. Neutrophil-lymphocyte ratio and C-reactive protein may be correlated in patients with coronary artery ectasia. Angiology. 2014;65(1):84-5.

14. Azab B, Shah N, Akerman M, McGinn JT, Jr. Value of platelet/lymphocyte ratio as a predictor of all-cause mortality after non-ST-elevation myocardial infarction. J Thromb Thrombolysis. 2012;34(3):326-34.

15. Roffi M, Patrono C, Collet JP, Mueller C, Valgimigli M, Andreotti F, et al. 2015 ESC Guidelines for the management of acute coronary syndromes in patients presenting without persistent ST-segment elevation: Task Force for the Management of Acute Coronary Syndromes in Patients Presenting without Persistent ST-Segment Elevation of the European Society of Cardiology (ESC). Eur Heart J. 2016;37(3):267-315.

16. Markis JE, Joffe CD, Cohn PF, Feen DJ, Herman MV, Gorlin R. Clinical significance of coronary arterial ectasia. Am J Cardiol. 1976;37(2):217-22.

17. Demopoulos VP, Olympios CD, Fakiolas CN, Pissimissis EG, Economides NM, Adamopoulou E, et al. The natural history of aneurysmal coronary artery disease. Heart. 1997;78(2):136-41.

18. Ozturk $S$, Yetkin E, Waltenberger J. Molecular and cellular insights into the pathogenesis of coronary artery ectasia. Cardiovasc Pathol. 2018;35:37-47.

19. Dogdus M, Kucukosmanoglu M, Kilic S. Assessment of the 
impact of isolated coronary artery ectasia on left ventricular functions with 3D speckle-tracking echocardiography.Echocardiography. 2019;36(12):2209-15.

20. Swaye PS, Fisher LD, Litwin P, Vignola PA, Judkins MP, Kemp HG, et al. Aneurysmal coronary artery disease. Circulation. 1983;67(1):134-8.

21. Yetkin $E$, Waltenberger J. Novel insights into an old controversy: is coronary artery ectasia a variant of coronary atherosclerosis? Clin Res Cardiol. 2007;96(6):331-9.

22. Doğduş $M$, Güler TE. İzole koroner arter ektazili hastalarda aterojenik dislipideminin araştırılması. Kocaeli Tıp Dergisi. 2019;8(2):173-81.

23. Huang QJ, Liu J, Chen MH, Li JJ. Relation of diabetes to coronary artery ectasia: A meta-analysis study. Anadolu Kardiyol Derg. 2014;14(4):322-7.

24. Thaulow E, Erikssen J, Sandvik L, Stormorken H, Cohn PF. Blood platelet count and function are related to total and cardiovascular death in apparently healthy men. Circulation. 1991;84(2):613-7.

25. Ommen SR, Gibbons RJ, Hodge DO, Thomson SP. Usefulness of the lymphocyte concentration as a prognostic marker in coronary artery disease. Am J Cardiol. 1997;79(6):812-4.

26. Boles $U$, Zhao $Y$, Rakhit $R$, Shiu MF, Papachristidis A, David $S$, et al. Patterns of coronary artery ectasia and short-term outcome in acute myocardial infarction. Scand Cardiovasc J. 2014;48(3):161-6.

27. Huang QJ, Zhang Y, Li XL, Li S, Guo YL, Zhu CG, et al. Clinical features of coronary artery ectasia in the elderly. J Geriatr Cardiol. 2014;11(3):185-91.

28. Heeschen C, Hamm CW, Bruemmer J, Simoons ML. Predictive value of $C$-reactive protein and troponin $T$ in patients with unstable angina: a comparative analysis. CAPTURE Investigators. Chimeric c7E3 AntiPlatelet Therapy in Unstable angina REfractory to standard treatment trial. J Am Coll Cardiol. 2000;35(6):1535-42.

29. Morrow DA, Rifai N, Antman EM, Weiner DL, McCabe CH, Cannon CP, et al. C-reactive protein is a potent predictor of mortality independently of and in combination with troponin T in acute coronary syndromes: a TIMI 11A substudy. Thrombolysis in Myocardial Infarction. J Am Coll Cardiol. 1998;31(7):1460-5. 